Article

\title{
Glycinebetaine-Induced Alteration in Gaseous Exchange Capacity and Osmoprotective Phenomena in Safflower (Carthamus tinctorius L.) under Water Deficit Conditions
}

\author{
Zanib Nazar ${ }^{1}$, Nudrat Aisha Akram ${ }^{1, *}$, Muhammad Hamzah Saleem ${ }^{2}$, Muhammad Ashraf ${ }^{3}$, \\ Shakeel Ahmed ${ }^{4}\left(\mathbb{D}\right.$, Shafaqat Ali ${ }^{5,6, *}$, Abdulaziz Abdullah Alsahli ${ }^{7}$ and \\ Mohammed Nasser Alyemeni ${ }^{7}$ \\ 1 Department of Botany, Government College University, Allama Iqbal Road, Faisalabad 38000, Pakistan; \\ Zanibnazar4916@gmail.com \\ 2 MOA Key Laboratory of Crop Ecophysiology and Farming System in the Middle Reaches of the \\ Yangtze River, College of Plant Science and Technology, Huazhong Agricultural University, Wuhan 430070, \\ China; saleemhamza312@webmail.hzau.edu.cn \\ 3 Department of Botany, University of Agriculture, Faisalabad 38040, Pakistan; ashrafbot@yahoo.com \\ 4 Instituto de Farmacia, Facultad de Ciencias, Universidad Austral de Chile, Valdivia 5110566, Chile; \\ shakeel1177@uach.cl \\ 5 Department of Environmental Sciences and Engineering, Government College University Allama \\ Iqbal Road, Faisalabad 38000, Pakistan \\ 6 Department of Biological Sciences and Technology, China Medical University, Taichung 40402, Taiwan \\ 7 Department of Botany and Microbiology, College of Science, King Saud University, Riyadh 11451, \\ Saudi Arabia; aalsahlaalshenaifi@ksu.edu.sa (A.A.A.); mnyemeni@ksu.edu.sa (M.N.A.) \\ * Correspondence: nudrataauaf@yahoo.com (N.A.A.); shafaqataligill@gcuf.edu.pk (S.A.)
}

Received: 3 December 2020; Accepted: 18 December 2020; Published: 20 December 2020

\begin{abstract}
Several inorganic and organic compounds including glycine betaine (GB) are presently being used as an exogenous application to enhance tolerance in plants to different environmental stresses. The current study assessed to what extent exogenously applied GB could improve the gaseous exchange capacity and primary and secondary metabolites in two accessions (16178 and 16180) of safflower (Carthamus tinctorius L.) plants under drought stress. Three-week-old plants of both safflower accessions were subjected to well-watered (control) or water-deficit conditions $(60 \%$ field capacity (FC)). Three levels of GB (control, $50 \mathrm{mM}$ and $100 \mathrm{mM}$ ) were sprayed to the foliage of the control and stressed plants after one month of drought application. After two weeks of foliar application of GB, gas exchange characteristics and other biochemical parameters were determined. The results showed that water deficiency markedly suppressed plant biomass, chlorophyll contents, photosynthesis rate $(A)$, water use efficiency $(A / E)$, stomatal conductance $\left(g_{s}\right)$ and relative water contents (RWC) of both accessions of safflower, while it enhanced the levels of osmolytes (GB and proline), hydrogen peroxide $\left(\mathrm{H}_{2} \mathrm{O}_{2}\right)$ and total phenolics. Foliar application of GB was effective in enhancing the plant biomass, chlorophyll contents, $g_{s}$, sub-stomatal $\mathrm{CO}_{2}$ concentration $\left(C_{i}\right), C_{i} / C_{a}$ ratio, osmolytes, $\mathrm{H}_{2} \mathrm{O}_{2}$, ascorbic acid (AsA), total phenolics and RWC in safflower plants under water shortage. Thus, exogenous application of GB could be used as an effective strategy to improve plant growth, photosynthetic attributes and secondary metabolites in safflower plants under water deficit conditions.
\end{abstract}

Keywords: glycine betaine; gaseous exchange; safflower; drought; metabolites 


\section{Introduction}

All plant processes are greatly influenced by deficiency of water as water is vital for their functioning [1,2]. Water deficiency even for a short time can disturb the growth and decrease the productivity of plants by disturbing photosynthesis [3,4]. Water-deficiency-induced impairment in photosynthesis is attributed to damaged composition of thylakoid membranes in chloroplasts as the lipid contents of cell membranes are susceptible to the ROS species produced as a result of drought [3-5]. Drought stress also disturbs gaseous exchange, metabolic activities, nutrient uptake, turgor and mitosis [6,7], which may lead to reduced growth and productivity [8-10] and sometimes the death of the plant $[11,12]$. Plants possess defensive systems primarily as antioxidants, which can effectively reduce the drastic effects of ROS species caused by water deficiency [13-17].

Among oil-seed-producing crops, safflower (Carthamus tinctorius) has a capacity of producing approximately $32-40 \%$ of high-quality seed oil [18] and is a very important economic crop. Its flowers and seeds are used to extract orange-red dye used as a flavoring agent for food and dye for coloring fabrics and edible oils $[19,20]$. Its oil is used to cook food for patients with cardiovascular diseases as it has a high content of linoleic acid antioxidants such as vitamin E [20,21]. In view of a number of reports, it is evident that this crop, with an inherent characteristic of a deep root system, is resistant to water deficiency and thus can be grown successfully in semi-arid and arid countries of the world facing problems of water shortage [22-24].

Nowadays, a number of compounds including osmoprotectants such as proline and glycine betaine (GB) are used with exogenous application to plants to reduce the harmful effects of abiotic stresses including drought stress. GB, a quaternary ammonium substance, is an osmoprotectant that can effectively scavenge ROS in plant tissues [25] and improves the photosynthesis rate by maintaining the Rubisco ultra-structure [26]. It is present in different amounts in different plant parts including seed, stem, root and flowers [25,27]. During the early juvenile stage of the plant, it is present in very small amounts in the roots but later increases in leaves $[27,28]$. Different levels of GB can be observed in different plant species under different abiotic stresses [29] depending on plant species, genotype, development stage, application modes and different stress conditions [30]. GB plays an essential role to provide protection from high accumulation of ROS species in plants under water shortage [25,28] and increases the photosynthetic defensive mechanism [26,31]. Rapid change in cellular metabolism, inferior level of water potential and ABA recognition sites give rise to accumulation of GB under water stress $[25,26,30]$. Furthermore, exogenously applied GB enhances yield and tolerance machinery by increasing chlorophyll contents, stimulating the antioxidant defensive system, decreasing ROS and stabilizing the photosynthesis ability of photosystem II under drought stress [32]. GB is believed to contribute to better protection when the concentration of ROS increases under severe water deficiency $[27,29]$. GB is believed to contribute to better protection when the concentration of ROS increases under severe water deficiency, so it has been hypothesized that exogenous application of organic compounds such as GB could mitigate the adverse effects of drought stress on safflower, a potential oil-producing crop. Therefore, the aim of the present study was to examine the role of exogenously applied GB in osmoprotection and gaseous exchange in safflower (Carthamus tinctorius L.) under water-deficit conditions.

\section{Materials and Methods}

\subsection{Plant Material and Growth Condition}

To evaluate the influence of exogenous application of varying levels of glycine betaine (GB) on inducing water-deficiency tolerance in safflower (Carthamus tinctorius L.), the present study was conducted under natural environmental conditions. The experiment was arranged in a completely randomized design (CRD) with three replications of each treatment. The seeds of two accessions of safflower i.e., 16178 and 16180, were collected from the Plant Genetic Resources Institute, National Agricultural Research Centre (PGRI, NARC), Islamabad, Pakistan. The experiment continued 
from January through March in the research garden area of the GC University Faisalabad, Pakistan. Each pot was filled with $0.41 \mathrm{~kg}$ (sandy loam), soil and five seeds were sown per pot. After one week of sowing, germination started. The seedlings that emerged were thinned to maintain three almost uniform-size seedlings per pot, and three pots were used for each treatment. After 21 days of seed germination, drought stress treatments, including control (normal watering) and drought ( $60 \%$ field capacity) were initiated. The given water levels were checked and maintained twice a week by weighting and adjusting the moisture level of the pots. After 30 days of drought stress, three levels of glycine betaine-control (no spray), $50 \mathrm{mM}$ and $100 \mathrm{mM}$-were applied as a foliar spray to stressed and non-stressed plants. After two-weeks of foliar-applied glycine betaine, plant samples were collected from each replicate, and root and shoot fresh weight were measured separately using an electrical balance after harvest. Then, the shoot and root samples were placed in an oven at $72{ }^{\circ} \mathrm{C}$ after air drying, and their dry weights were recorded. Fresh leaf samples were preserved at $-20^{\circ} \mathrm{C}$ for the determination of the following attributes.

\subsection{Chlorophyll Contents}

Following Arnon [33], chlorophyll $a$ and $b$ contents were determined. A proportion $(0.25 \mathrm{~g})$ of fresh leaf was extracted in $5 \mathrm{~mL}$ of $80 \%$ acetone with the help of a mortar and pestle. Then, the mixture was homogenized and kept overnight at $4{ }^{\circ} \mathrm{C}$. The absorbance of the supernatant was recorded at 663 and $645 \mathrm{~nm}$ using a UV-visible spectrophotometer.

\subsection{Gas Exchange Parameters}

Gas exchange parameters such as rate of transpiration $(E)$, photosynthetic rate $(A)$, stomatal conductance $\left(g_{s}\right)$, internal $\mathrm{CO}_{2}$ concentration $(C i)$ and water use efficiency $(A / E)$ were determined using an Infra Red Gas Analyzer (IRGA). The data were recorded at daytime with maximum sunshine.

\subsection{Free Proline}

The proline content was estimated using the procedure of Bates et al. [34]. A fresh plant leaf $(0.25 \mathrm{~g})$ of each sample was homogenized finely in $5 \mathrm{~mL}$ of $(3 \% \mathrm{w} / \mathrm{v})$ sulfosalicylic acid and then centrifuged. To $2.0 \mathrm{~mL}$ of the extract, $2 \mathrm{~mL}$ of ninhydrin and $2 \mathrm{~mL}$ of glacial acetic acid were added. This mixture was heated for $1 \mathrm{~h}$ at $95^{\circ} \mathrm{C}$. Toluene $(4 \mathrm{~mL})$ was added to the cooled sample mixture. The mixture was shaken vigorously, and two layers were formed. The absorbance of the upper layer was read at $520 \mathrm{~nm}$.

\subsection{Glycine Betaine (GB) Contents}

The Grieve and Grattan [35] method was employed to determine glycine betaine contents. According to this method, dry leaf $(0.25 \mathrm{~g})$ was shaken in $10 \mathrm{~mL}$ toluene $(0.5 \%)$ and kept at $4{ }^{\circ} \mathrm{C}$ overnight. Then, the mixture was filtered. To $1 \mathrm{~mL}$ of the filtrate, $1 \mathrm{~mL}$ of $2 \mathrm{~N} \mathrm{H}_{2} \mathrm{SO}_{4}$ and $0.2 \mathrm{~mL}$ of $\mathrm{KI}_{3}$ were added. This mixture was cooled for $90 \mathrm{~min}$, and then $2.8 \mathrm{~mL}$ of de-ionized $\mathrm{H}_{2} \mathrm{O}$ and $6 \mathrm{~mL}$ of 1 , 2 dichloroethane were added to it and centrifuged. The upper layer was discarded, but the lower layer was read at $365 \mathrm{~nm}$ using a spectrophotometer.

\subsection{Hydrogen Peroxide $\left(\mathrm{H}_{2} \mathrm{O}_{2}\right)$ Concentration}

The hydrogen peroxide content was estimated using the method of Velikova et al. [36]. Fresh leaf $(0.5 \mathrm{~g})$ was homogenized in $5 \mathrm{~mL}$ trichloroacetic acid $(0.1 \%$; $w / v)$ using a mortar and pestle. After filtering the extract, an aliquot of the supernatant $(500 \mu \mathrm{L})$ was taken in a test tube, and $1 \mathrm{~mL}$ of potassium iodide and $0.5 \mathrm{~mL}$ of phosphate buffer were added to it. The test tubes were kept at room temperature for $20 \mathrm{~min}$, and absorbance was recorded at $390 \mathrm{~nm}$ using a spectrophotometer. 


\subsection{Malondialdehyde (MDA) Contents}

According to the method of Cakmak and Horst [37], malondialdehyde contents were determined. TBA (thiobarbituric acid) was used for the determination of lipid peroxidation in leaf samples. A fresh leaf $(0.25 \mathrm{~g})$ was homogenized in $5 \mathrm{~mL}$ of $1 \%(w / v)$ trichloroacetic acid (TCA). The mixture was centrifuged at 15,000 rpm for $10 \mathrm{~min}$. An aliquot of the supernatant $(500 \mu \mathrm{L})$ was treated with $2 \mathrm{~mL}$ of $0.5 \%$ thiobarbituric acid (TBA), which was prepared in 20\% TCA. After that, this mixture was boiled at $100{ }^{\circ} \mathrm{C}$ for $30 \mathrm{~min}$ and cooled in an ice bath. The optical density (OD) of the treated mixture was recorded at 600 and $532 \mathrm{~nm}$ using a spectrophotometer.

\subsection{Total Phenolics}

Total phenolic content was determined according to the method of Julkenen-Titto [38] using Folin and Ciocalteau's phenol reagent. According to this protocol, fresh leaf $(0.25 \mathrm{~g})$ was extracted in $80 \%$ acetone solution $(5 \mathrm{~mL})$. Then, the extract was filtered through a filter paper. To an aliquot $(100 \mu \mathrm{L})$ of the supernatant, $2 \mathrm{~mL}$ of distilled water and one $\mathrm{mL}$ of Folin Phenol Ciocalteau's reagent were added and the mixture was strongly shaken. Then $5 \mathrm{~mL}$ of $20 \%$ sodium carbonate $\left(\mathrm{Na}_{2} \mathrm{CO}_{3}\right)$ was added to the mixture and made to be a final volume of $10 \mathrm{~mL}$ with distilled water. The amount of total phenolics was estimated by reading the treated samples at $750 \mathrm{~nm}$ using a spectrophotometer.

\subsection{Ascorbic Acid Content}

Ascorbic acid content was measured according to the method of Mukherjee and Choudhuri [39]. A fresh leaf $(0.25 \mathrm{~g})$ was ground in $10 \mathrm{~mL}$ of $6 \%$ TCA $(w / v)$, and the extract was filtered. To $1 \mathrm{~mL}$ of the filtrate contained in a test tube, $2 \mathrm{~mL}$ of dinitrophenyl hydrazine prepared in $9 \mathrm{~N} \mathrm{H}_{2} \mathrm{SO}_{4}$ and one drop of $10 \%$ thiourea (in $70 \%$ ethanol) solution were added. The mixture was boiled for $15 \mathrm{~min}$ at $100{ }^{\circ} \mathrm{C}$ and cooled at room temperature. Then, $5 \mathrm{~mL}$ of $80 \%(v / v) \mathrm{H}_{2} \mathrm{SO}_{4}$ was added to the mixture. Absorbance of the samples was recorded at $530 \mathrm{~nm}$ spectrophotometrically.

\subsection{Relative Water Contents (RWC)}

This was calculated using the method of Barrs and Weatherby [40]. Fresh leaf samples were collected from each replicate, and the fresh weight was recorded. Immediately afterward, the leaves were dipped in water for $2 \mathrm{~h}$ at room temperature. The leaves were then taken out of the water, extra moisture was dried with a filter paper, and turgid weight was recorded. Afterward, the leaf samples were kept in an oven for $48 \mathrm{~h}$ and weighed again, and the dry weight was recorded.

\subsection{Statistical Analysis}

Analysis of variance of data was worked out using the Cohort Statistical program. In addition, correlations were determined between plant growth and other biochemical attributes. Mean data were compared at a $0.05 \%$ probability level. Graphical presentation was conducted using Origin Pro-2017. Correlation between different variables studied in this experiment was conducted using RStudio. Similarly, the principal component analysis was also conducted to study different components in safflower using RStudio.

\section{Results}

\subsection{Growth Attributes}

A marked $(p \leq 0.001)$ decrease was observed in the biomass production (fresh and dry weight of root and shoot) of both accessions (16178 and 16180) of safflower under drought stress (Table 1). However, foliar-applied glycine betaine (GB) significantly $(p \leq 0.001)$ improved plant fresh and dry biomass in both accessions of safflower under control (unstressed plants) and water stress conditions (Table 1). Of both GB levels, $100 \mathrm{mM}$ was more effective in enhancing the plant biomass (Figure 1). 
No significant difference was observed between both accessions of safflower in terms of biomass production (Figure 1). Drought stress significantly decreased the lengths of the shoot $(p \leq 0.01)$ and $\operatorname{root}(p \leq 0.001)$ in both accessions (Table 1$)$. In contrast, exogenous application of GB was effective in improving the shoot $(p \leq 0.01)$ and root $(p \leq 0.001)$ lengths in both accessions (Table 1). Exogenous application of $50 \mathrm{mM} \mathrm{GB}$ was found to be as effective as $100 \mathrm{mM} \mathrm{GB}$ in promoting shoot and root lengths (Figure 1).
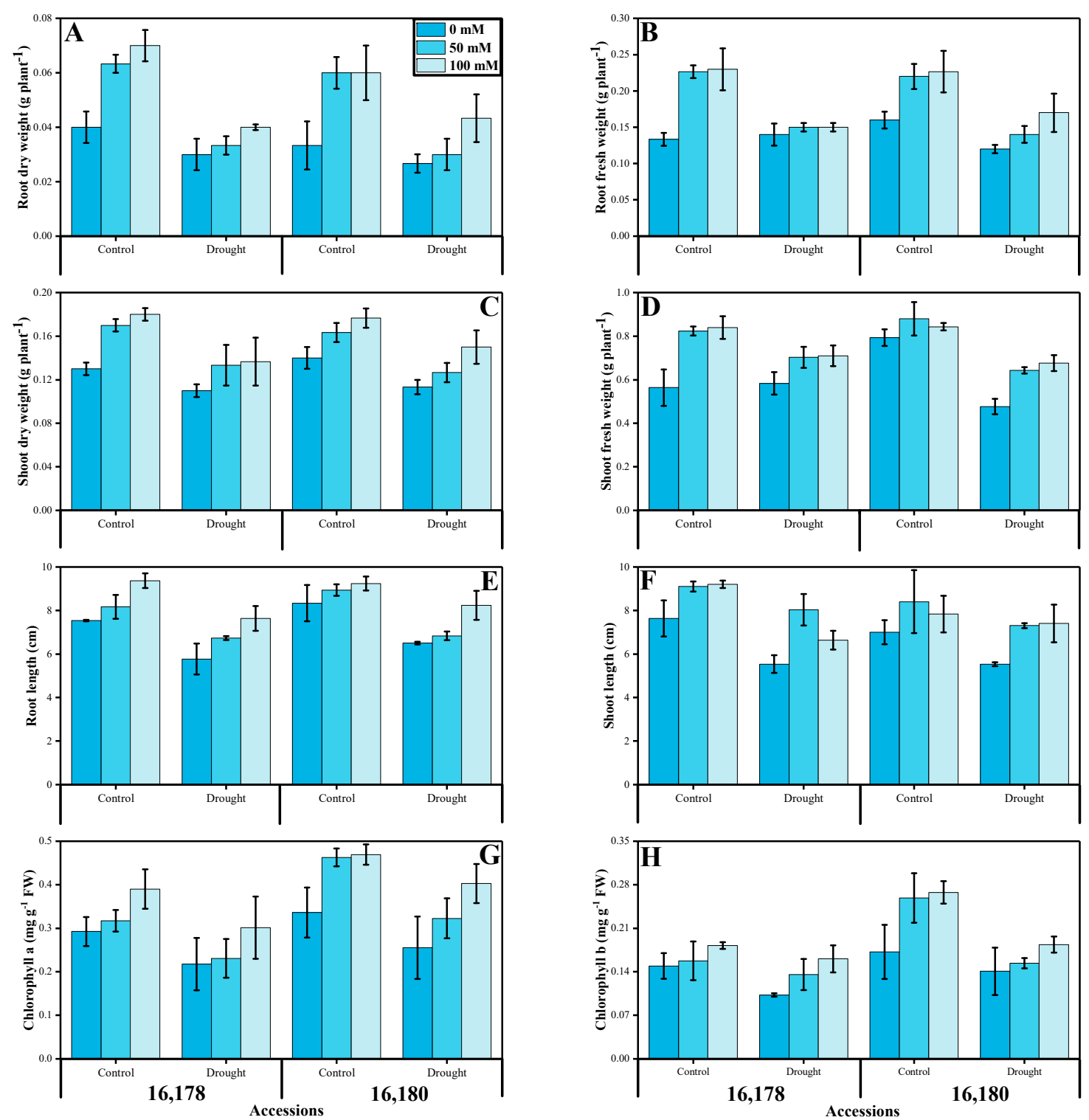

Figure 1. Effect of different concentrations of exogenous application of glycine betaine $(0,50$ and $100 \mathrm{mM}$ ) on root dry weight (A), root fresh weight (B), shoot dry weight (C), shoot fresh weight (D), root length (E), shoot length $(\mathbf{F})$, chlorophyll a $(\mathbf{G})$ and chlorophyll b contents $(\mathbf{H})$ of safflower (acessions) grown under control (normal watering) and drought (60\% field capacity) stressed environments. Bars sharing different letter(s) for each parameter are significantly different from each other according to Duncan's multiple range test $(p<0.05)$. All the data represent the average of three replications $(n=3)$. Error bars represent standard deviation (SD) of three replicates. 
Table 1. Mean squares from three-way analysis of variance of data for biomass and different biochemical processes of safflower (Carthamus tinctoris L.) foliarly applied glycine betaine (GB) under water deficit conditions.

\begin{tabular}{|c|c|c|c|c|c|c|c|}
\hline $\begin{array}{l}\text { Source of } \\
\text { Variations }\end{array}$ & df & Shoot FW & Shoot DW & Root FW & Root DW & Shoot Length & Root Length \\
\hline Cultivars (Cv) & 1 & $0.0020 \mathrm{~ns}$ & $2.5 \mathrm{~ns}$ & $1.111 \mathrm{~ns}$ & $1.361 \mathrm{~ns}$ & $1.777 \mathrm{~ns}$ & $2.054 \mathrm{~ns}$ \\
\hline Drought stress (D) & 1 & $0.2256^{* * *}$ & $0.0090^{* * *}$ & $0.026 * * *$ & $0.003 * * *$ & $19.067^{* *}$ & $24.337 * * *$ \\
\hline $\mathrm{Cv} \times \mathrm{D}$ & 1 & $0.0600 * *$ & $2.5 \mathrm{~ns}$ & $1.777 \mathrm{~ns}$ & $6.944 \mathrm{~ns}$ & $1.867 \mathrm{~ns}$ & $6.933 \mathrm{~ns}$ \\
\hline $\mathrm{Cv} \times \mathrm{T}$ & 2 & $0.0050 \mathrm{~ns}$ & $1.583 \mathrm{~ns}$ & $2.194 \mathrm{~ns}$ & $2.777 \mathrm{~ns}$ & $0.166 \mathrm{~ns}$ & $0.217 \mathrm{~ns}$ \\
\hline $\mathrm{D} \times \mathrm{T}$ & 2 & $0.0009 \mathrm{~ns}$ & $1.583 \mathrm{~ns}$ & $0.003 *$ & $3.694 \mathrm{~ns}$ & $0.371 \mathrm{~ns}$ & $0.174 \mathrm{~ns}$ \\
\hline $\mathrm{Cv} \times \mathrm{D} \times \mathrm{T}$ & 2 & $0.0181 \mathrm{~ns}$ & $1.083 \mathrm{~ns}$ & $9.361 \mathrm{~ns}$ & $3.611 \mathrm{~ns}$ & $0.923 \mathrm{~ns}$ & $0.37 \mathrm{~ns}$ \\
\hline Error & & Chlorophyll $a$ & Chlorophyll $b$ & Total Chlorophyll & $\begin{array}{c}\text { Chlorophyll } a / b \\
\text { Ratio }\end{array}$ & $\begin{array}{c}\text { Photosynthetic } \\
\text { Rate }(A)\end{array}$ & $\begin{array}{c}\text { Transpiration } \\
\text { Rates }(E)\end{array}$ \\
\hline Cultivars (Cv) & 1 & $0.062 * *$ & $0.0207^{* *}$ & $0.007 \mathrm{~ns}$ & $0.095 \mathrm{~ns}$ & $0.232 \mathrm{~ns}$ & 0.011 * \\
\hline Drought stress (D) & 1 & $0.072 * *$ & $0.0239 * *$ & $0.322 * * *$ & $0.069 \mathrm{~ns}$ & $14.83^{* * *}$ & $0.0096 \mathrm{~ns}$ \\
\hline Treatment $(\mathrm{T})$ & 2 & $0.039^{* *}$ & $0.010 *$ & $0.018 \mathrm{~ns}$ & $0.181 \mathrm{~ns}$ & $0.817 \mathrm{~ns}$ & $0.0073 \mathrm{~ns}$ \\
\hline $\mathrm{Cv} \times \mathrm{D}$ & 1 & $3.508 \mathrm{~ns}$ & $0.004 \mathrm{~ns}$ & $0.219 * * *$ & $0.861 \mathrm{~ns}$ & $1.899 *$ & $0.0084 \mathrm{~ns}$ \\
\hline $\mathrm{CV} \times \mathrm{T}$ & 2 & $0.004 \mathrm{~ns}$ & $7.303 \mathrm{~ns}$ & $0.001 \mathrm{~ns}$ & $0.039 \mathrm{~ns}$ & $0.033 \mathrm{~ns}$ & $0.0019 \mathrm{~ns}$ \\
\hline $\mathrm{D} \times \mathrm{T}$ & 2 & $0.001 \mathrm{~ns}$ & $4.515 \mathrm{~ns}$ & $9.113 \mathrm{~ns}$ & $0.016 \mathrm{~ns}$ & $0.15 \mathrm{~ns}$ & $0.027 \mathrm{~ns}$ \\
\hline Error & & $\begin{array}{c}\text { Stomatal } \\
\text { Conductance (gs) }\end{array}$ & $\begin{array}{l}\text { Sub-stomatal } \mathrm{CO}_{2} \\
\text { Concentration }\left(C_{i}\right)\end{array}$ & $C_{i} / C_{a}$ ratio & $\begin{array}{c}\text { Water-Use } \\
\text { Efficiency(A/E) }\end{array}$ & Proline & GB \\
\hline Cultivars (Cv) & 1 & $498.77^{* *}$ & $3664.2 *$ & $0.0295 *$ & $29.71 \mathrm{~ns}$ & $90.342^{* * *}$ & $5460.05^{* * *}$ \\
\hline Drought stress (D) & 1 & $484^{* *}$ & $3098.7 \mathrm{~ns}$ & $0.0250 \mathrm{~ns}$ & 130.06 * & $37.394^{* * *}$ & $415.1 \mathrm{~ns}$ \\
\hline Treatment $(\mathrm{T})$ & 2 & $206.58 *$ & $4054.8^{*}$ & $0.0327^{*}$ & $7.203 \mathrm{~ns}$ & $7.086^{* *}$ & $897.8 *$ \\
\hline $\mathrm{Cv} \times \mathrm{D}$ & 1 & $113.7 \mathrm{~ns}$ & $536.6 \mathrm{~ns}$ & $0.0043 \mathrm{~ns}$ & $1.5059 \mathrm{~ns}$ & $2.393 \mathrm{~ns}$ & $0.458 \mathrm{~ns}$ \\
\hline $\mathrm{Cv} \times \mathrm{T}$ & 2 & $35.19 \mathrm{~ns}$ & $16.603 \mathrm{~ns}$ & $1.34 \mathrm{~ns}$ & $23.3928 \mathrm{~ns}$ & $0.034 \mathrm{~ns}$ & $930.7 *$ \\
\hline $\mathrm{D} \times \mathrm{T}$ & 2 & $8.5833 \mathrm{~ns}$ & $46.92 \mathrm{~ns}$ & $3.7875 \mathrm{~ns}$ & $5.4902 \mathrm{~ns}$ & $0.344 \mathrm{~ns}$ & $1733.8^{* *}$ \\
\hline $\mathrm{Cv} \times \mathrm{D} \times \mathrm{T}$ & 2 & $16.861 \mathrm{~ns}$ & 408.3 ns & $0.0032 \mathrm{~ns}$ & $1.1206 \mathrm{~ns}$ & $0.476 \mathrm{~ns}$ & $1331.3^{* *}$ \\
\hline Error & 24 & 41.75 & 807.6 & 0.0065 & 18.796 & 1.031 & 234.9 \\
\hline
\end{tabular}


Table 1. Cont

\begin{tabular}{|c|c|c|c|c|c|c|c|}
\hline $\begin{array}{c}\text { Source of } \\
\text { Variations }\end{array}$ & df & Shoot FW & Shoot DW & Root FW & Root DW & Shoot Length & Root Length \\
\hline & & MDA & AsA & $\mathrm{H}_{2} \mathrm{O}_{2}$ & Total Phenolics & RWC & \\
\hline Cultivars $(\mathrm{Cv})$ & $\mathrm{df}$ & $1.078 \mathrm{~ns}$ & $3.187 \mathrm{~ns}$ & $13337 * * *$ & $199.28^{* * *}$ & $344.0 *$ & \\
\hline Drought stress (D) & 1 & $3.914 \mathrm{~ns}$ & $17.490 \mathrm{~ns}$ & $211408.3^{* * *}$ & $390.72 * * *$ & $757.4^{* * *}$ & \\
\hline Treatment $(\mathrm{T})$ & 1 & $21.825 \mathrm{~ns}$ & $19.689 *$ & $44144.0^{* *}$ & $102.68^{* *}$ & $182.5 *$ & \\
\hline $\mathrm{Cv} \times \mathrm{D}$ & 2 & $17.647 \mathrm{~ns}$ & $4.765 \mathrm{~ns}$ & $10378.5 \mathrm{~ns}$ & $1.52 \mathrm{~ns}$ & $1.028 \mathrm{~ns}$ & \\
\hline $\mathrm{Cv} \times \mathrm{T}$ & 1 & $0.756 \mathrm{~ns}$ & $2.573 \mathrm{~ns}$ & $6929.9 \mathrm{~ns}$ & $94.39 * *$ & $6.005 \mathrm{~ns}$ & \\
\hline $\mathrm{D} \times \mathrm{T}$ & 2 & $2.337 \mathrm{~ns}$ & $1.891 \mathrm{~ns}$ & $1049.7 \mathrm{~ns}$ & $10.0 \mathrm{~ns}$ & $14.29 \mathrm{~ns}$ & \\
\hline $\mathrm{Cv} \times \mathrm{D} \times \mathrm{T}$ & 2 & $1.040 \mathrm{~ns}$ & $2.233 \mathrm{~ns}$ & $44941.7^{* *}$ & $37.02 \mathrm{~ns}$ & $10.39 \mathrm{~ns}$ & \\
\hline Error & 2 & 8.276 & 4.190 & 6175.0 & 11.032 & $51.24 \mathrm{~ns}$ & \\
\hline
\end{tabular}




\subsection{Chlorophyll Pigments}

A slightly reducing effect of drought stress was observed on chlorophyll $a$ and $b$ contents ( $p \leq 0.01$ ) and total chlorophyll contents $(p \leq 0.001)$, while no significant effect was observed on chlorophyll $\mathrm{a} / \mathrm{b}$ ratio in both safflower accessions (Table 1). Drought-induced reduction in chlorophyll $a$ and $b$ contents was more prominent in accession of 16178 than in the other accession, while no prominent difference between the two accessions was observed on total chlorophyll contents (Figures 1 and 2 ). The foliar-applied GB enhanced the chlorophyll $a(p \leq 0.01)$ and $b$ contents $(p \leq 0.05)$ being more prominent in accession 16180 (Table 1, Figure 1). While no significant effects of foliar-applied GB were observed on total chlorophyll contents and chlorophyll $a / b$ ratio (Table 1 ). There was no significant difference between both levels (50 and $100 \mathrm{mM}$ ) of foliar-applied GB on chlorophyll $a / b$ ratio (Figures 1 and 2).
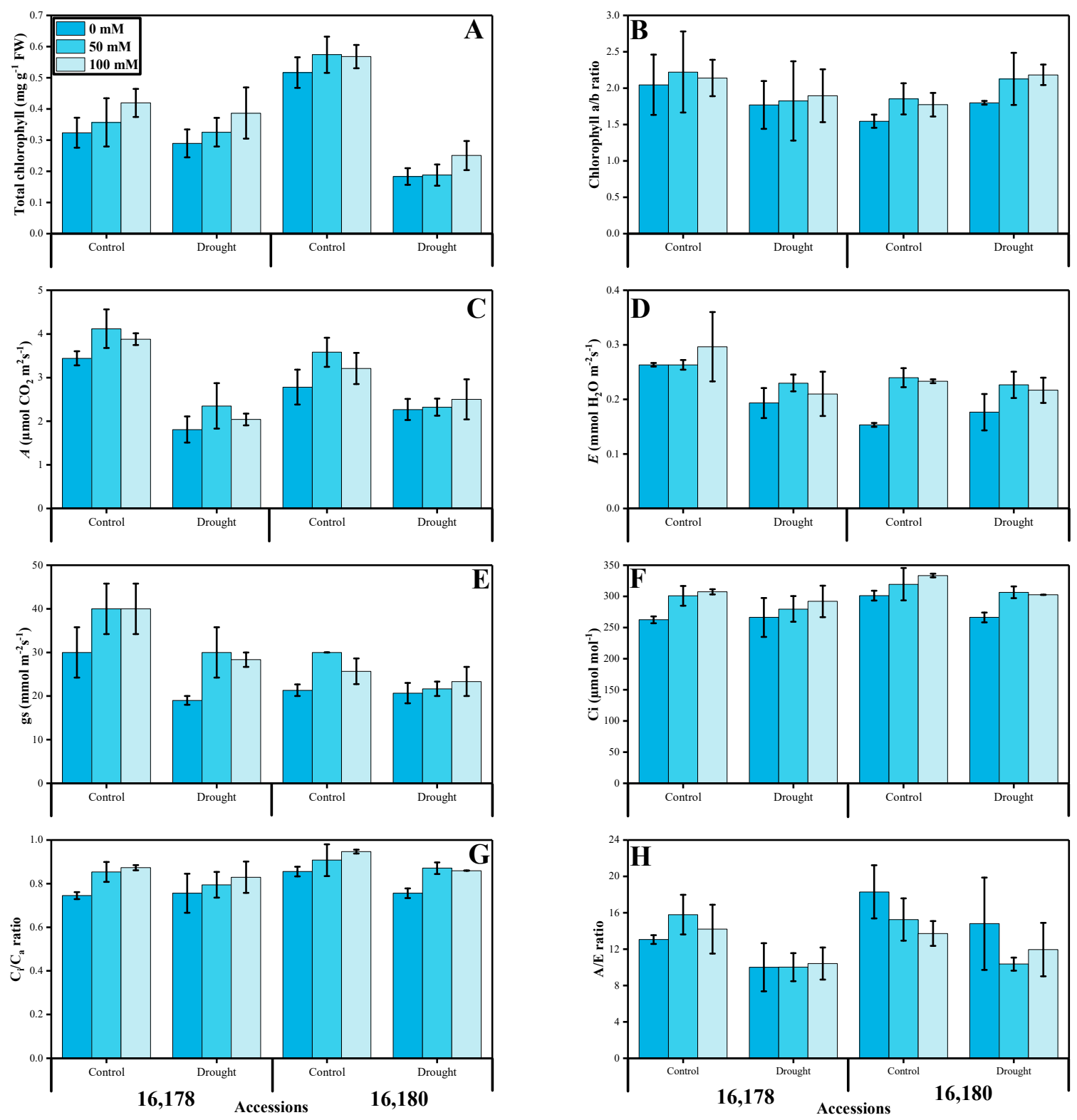

Figure 2. Effect of different concentrations of exogenous application of glycine betaine $(0,50$ and $100 \mathrm{mM}$ ) on total chlorophyll (A), chlorophyll $a / b$ (B), photosynthetic rate (C), transpiration rates (D), stomatal conductance $(\mathbf{E})$, sub-stomatal $\mathrm{CO}_{2}$ concentration $(\mathbf{F}), C_{i} / C_{a}$ ratio $(\mathbf{G})$ and water-use efficiency (H) of safflower (accessions) grown under control (normal watering) and drought (60\% field capacity) 
stressed environment. Bars sharing different letter(s) for each parameter are significantly different from each other according to Duncan's multiple range test $(p<0.05)$. All the data represent the average of three replications $(n=3)$. Error bars represent standard deviation (SD) of three replicates.

\subsection{Gas Exchange Characteristics}

Drought stress significantly decreased stomatal conductance $\left(g_{s}\right)(p \leq 0.01)$, photosynthetic rate $(A)$ $(p \leq 0.001)$ and water use efficiency $(A / E)(p \leq 0.05)$, while it had no significant effect on transpiration rate $(E)$, sub-stomatal $\mathrm{CO}_{2}$ concentration $\left(C_{i}\right)$ and $C_{i} / C_{a}$ ratio (Table 1$)$. Foliarly applied GB increased stomatal conductance $\left(g_{s}\right)$, sub-stomatal $\mathrm{CO}_{2}$ concentration $\left(C_{i}\right)$ and $C_{i} / C_{a}$ ratio significantly $(p \leq 0.05)$, while it had no effect on photosynthetic rate, transpiration rate and water use efficiency (Table 1). In 16178 accession, the effects of drought on stomatal conductance, photosynthetic rate and GB on stomatal conductance were more prominent than those on the other accession (Figure 2). Both levels (50 and $100 \mathrm{mM}$ ) of GB were equally effective in affecting the gas exchange attributes (Figure 2).

\subsection{Osmoprotectants}

Drought stress increased proline contents significantly $(p \leq 0.001)$ in both accessions of safflower, being more marked in accession 16180, while it had a non-significant effect on GB accumulation (Table 1, Figure 3). Exogenous application of GB enhanced proline $(p \leq 0.01)$ and GB $(p \leq 0.05)$ accumulation in both safflower accessions, but it was more prominent in accession 16180 (Figure 3, Table 1). Both levels of GB had a similar effect on intrinsic GB accumulation (Figure 3).

\subsection{Lipid Peroxidation}

Drought stress significantly $(p \leq 0.001)$ increased the production of hydrogen peroxide $\left(\mathrm{H}_{2} \mathrm{O}_{2}\right)$ in both safflower accessions, while it did not affect the MDA levels (Table 1). A significant $(p \leq 0.001)$ increase was observed in stressed plants due to foliar-applied GB as compared to that in the control plants of both accessions, while no significant effect of GB application was observed on MDA levels (Table 1). A promising increase in $\mathrm{H}_{2} \mathrm{O}_{2}$ contents was observed in accession 16180 due to foliar-applied 50 mM GB (Figure 3).

\subsection{Antioxidants}

A considerable $(p \leq 0.001)$ increase in total phenolics was observed in both safflower accessions under water shortage, being more prominent in 16178 accession, while it had a non-significant effect on AsA contents (Table 1). Exogenous application of $50 \mathrm{mM}$ as well as $100 \mathrm{mM}$ GB significantly improved the AsA contents $(p \leq 0.05)$ and total phenolics $(p \leq 0.01)$ under drought stress (Table 1$)$. The effect of GB application on total phenolics was more prominent in accession 16178 than that in the other accession (Figure 3).

\subsection{Relative Water Content}

Drought stress significantly $(p \leq 0.001)$ reduced the RWC of both safflower accessions. Externally applied both GB levels significantly $(p \leq 0.05)$ enhanced the relative water content in both safflower accessions (Table 1; Figure 3). 

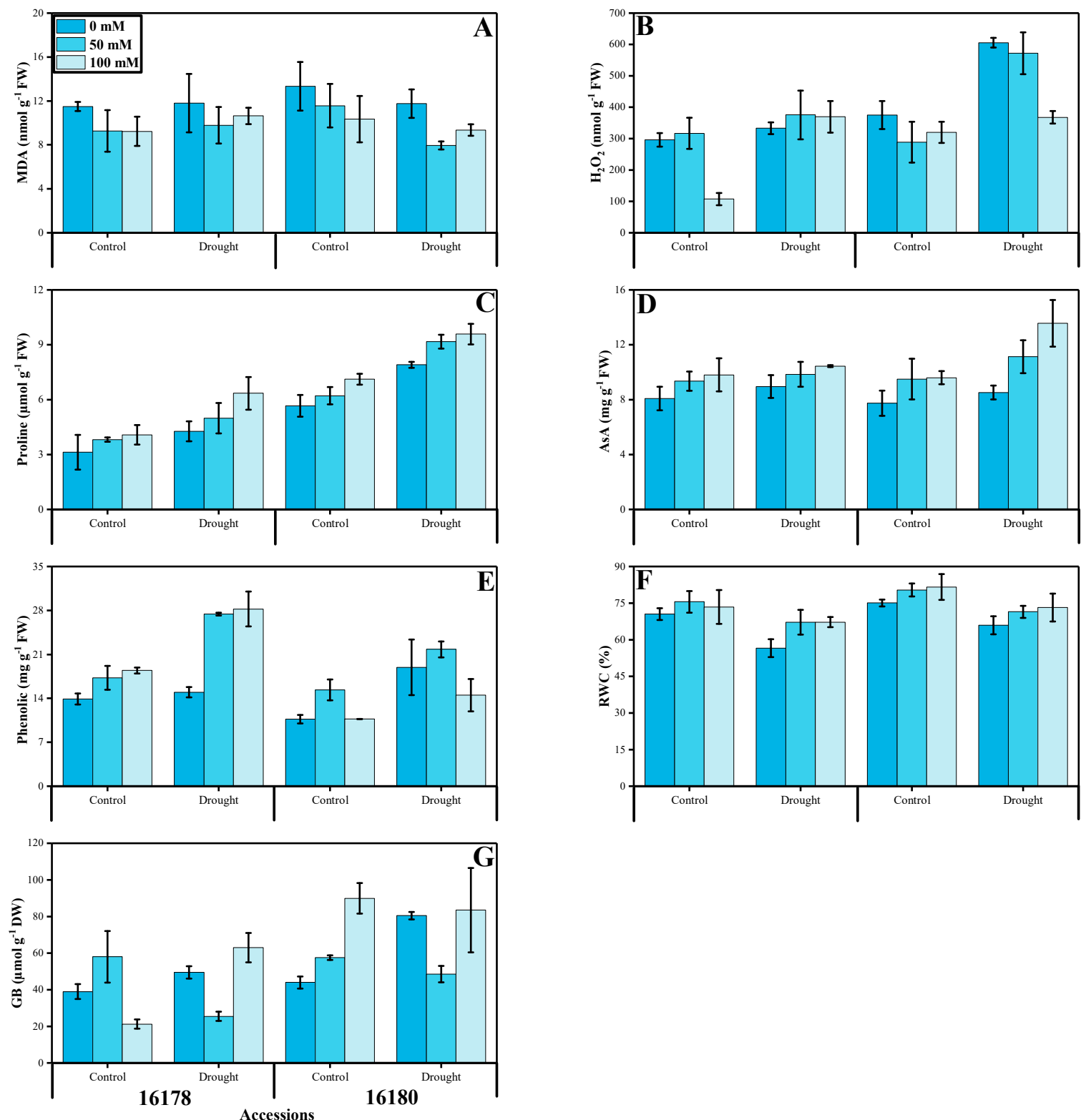

Figure 3. Effect of different concentrations of exogenous application of glycine betaine $(0,50$ and $100 \mathrm{mM}$ ) on malondialdehyde (A), hydrogen peroxide (B), proline (C), ascorbic acid (D), total phenolics $($ E), relative water content $(\mathbf{F})$ and glycine betaine $(\mathbf{G})$ content of safflower (acessions) grown under control (normal watering) and drought (60\% field capacity) stressed environments. Bars sharing different letter(s) for each parameter are significantly different from each other according to Duncan's multiple range test $(p<0.05)$. All the data represent the average of three replications $(n=3)$. Error bars represent standard deviation (SD) of three replicates.

\subsection{Relationship}

The Pearson correlation analysis was carried out to quantify the relationship between GB with growth, photosynthetic measurements, oxidative stress and antioxidants (Figure 4). The contents of GB were positively correlated with hydrogen peroxide, malondialdehyde, phenolic, proline and ascorbic acid while negatively correlated with root dry weight, root fresh weight, shoot dry weight, shoot fresh weight, root length, shoot length, chlorophyll a, chlorophyll b contents, total chlorophyll, chlorophyll $a / b$, photosynthetic rate, transpiration rate, stomatal conductance, sub-stomatal $\mathrm{CO}_{2}$ concentration, $C_{i} / C_{a}$ ratio, relative water contents and water-use efficiency. In addition, both accessions showed the 
same trend under the application of GB under controlled and water stress condition, so we studied only 16178. This correlation reflected the close connection between GB and growth in safflower.

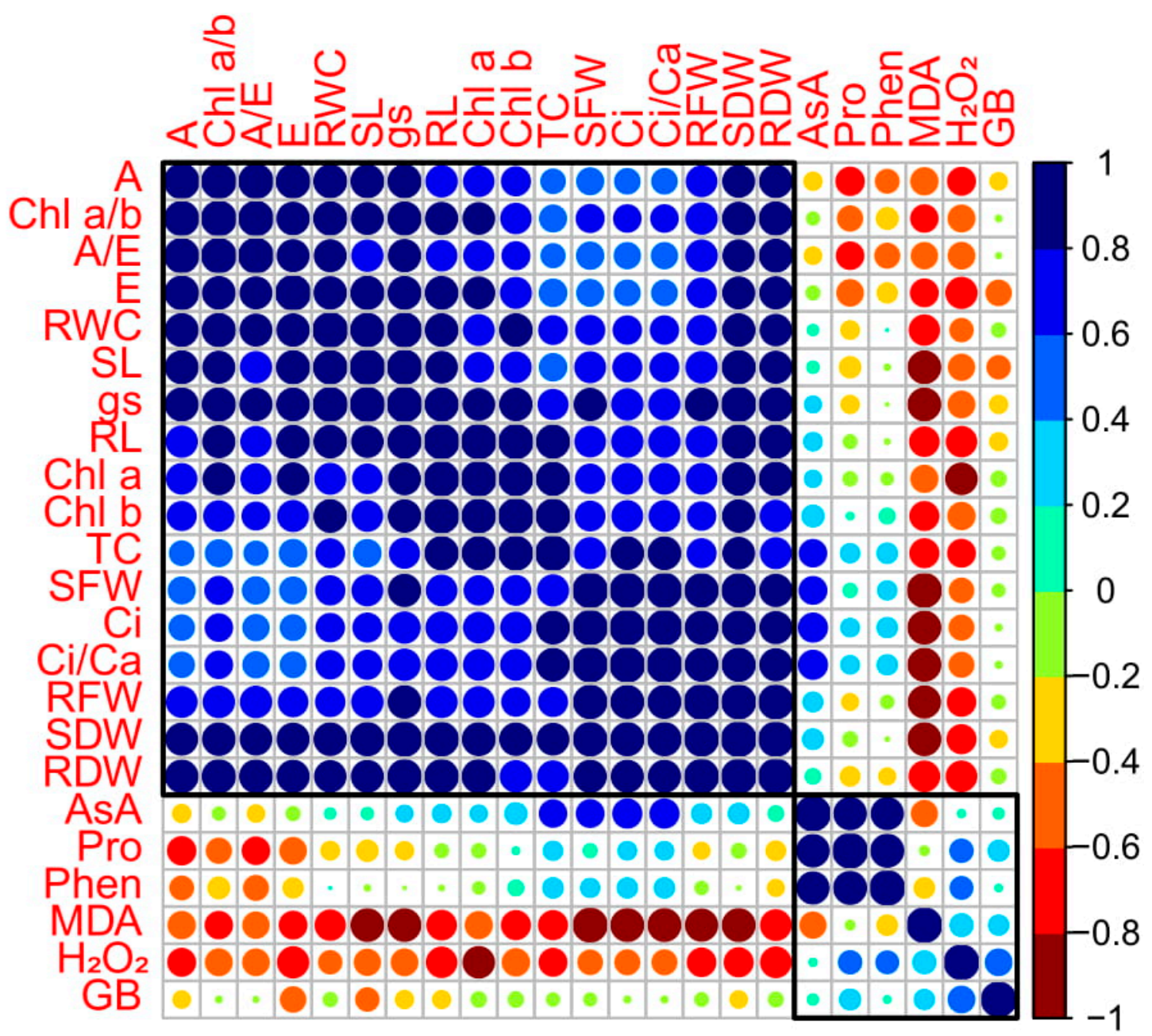

Figure 4. Correlation between GB and growth, photosynthetic measurements, oxidative stress and antioxidants in safflower. Different abbreviations used in this study are as follows: A (photosynthetic rate), $\mathrm{Chl} \mathrm{a} / \mathrm{b}$ (chlorophyll $\mathrm{a} / \mathrm{b}$ ), $\mathrm{A} / \mathrm{E}$ (water-use efficiency), SL (shoot length), gs (stomatal conductance), RL (root length), Chl a (chlorophyll a contents), Chl b (chlorophyll b contents), TC (total chlorophyll contents), SFW (shoot fresh weight), $\mathrm{Ci}$ (sub-stomatal $\mathrm{CO}_{2}$ concentration), $\mathrm{Ci} / \mathrm{Ca}\left(C_{i} / C_{a}\right.$ ratio), $\mathrm{RFW}$ (root fresh weight), SDW (shoot dry weight), RDW (root dry weight), AsA (ascorbic acid contents), Pro (proline contents), Phen (phenolic contents), MDA (malondialdehyde contents), $\mathrm{H}_{2} \mathrm{O}_{2}$ (hydrogen peroxide initiation) and GB (glysine betain contents).

\subsection{Principal Component Analysis}

The loading plots of principal component analysis (PCA) to evaluate the effects of various levels GB on growth, photosynthetic measurements, oxidative stress and antioxidants in safflower (16178) are presented in Figure 5. Among all the principal components, the first two components, i.e., PC1 (Dim 1) and PC2 (Dim 2), exhibited maximum contribution and accounted for $85 \%$ of the total variance in the dataset. Of these, PC1 contributed $65.9 \%$, while PC2 contributed $19.3 \%$. The first group of variables with which PC1 is positively correlated includes: root dry weight, root fresh weight, shoot dry weight, shoot fresh weight, root length, shoot length, chlorophyll a, chlorophyll b contents, total chlorophyll, chlorophyll $a / b$, photosynthetic rate, transpiration rate, stomatal conductance, sub-stomatal $\mathrm{CO}_{2}$ concentration, $C_{i} / C_{a}$ ratio, relative water contents and water-use efficiency. A significant negative 
correlation of PC1 variables was found with the variables aligned with PC2: hydrogen peroxide, malondialdehyde, phenolic, proline, ascorbic acid and GB.

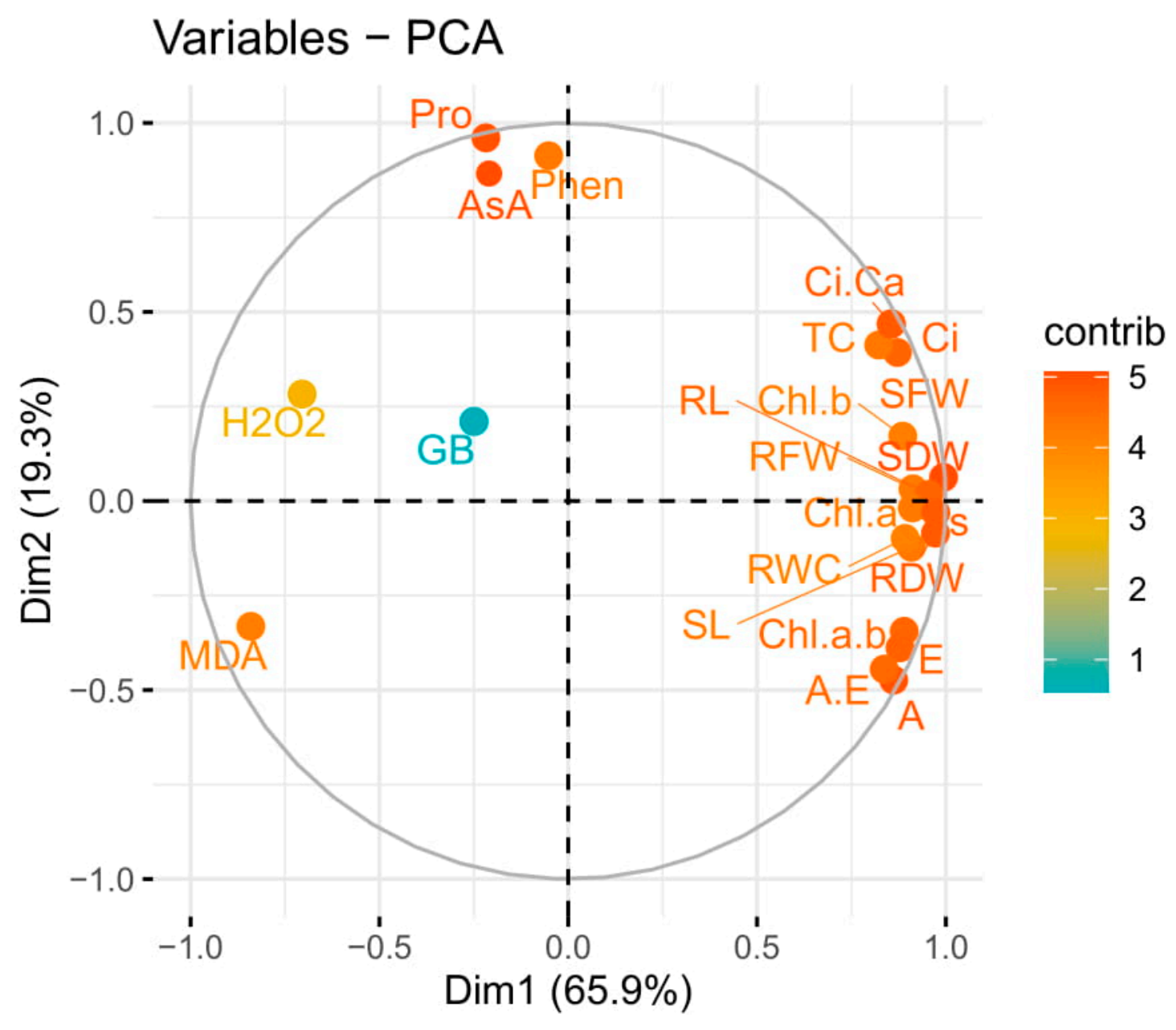

Figure 5. Loading plots of principal component analysis (PCA) on different studied attributes of safflower (16178) grown under different concentrations of exogenous application of glycine betaine $(0,50$ and $100 \mathrm{mM})$ grown in control (normal watering) and drought (60\% field capacity) stressed environments. Different abbreviations used in this study are as follows: A (photosynthetic rate), Chl a/b (chlorophyll $a / b$ ), A/E (water-use efficiency), SL (shoot length), gs (stomatal conductance), RL (root length), $\mathrm{Chl}$ a (chlorophyll a contents), $\mathrm{Chl} \mathrm{b}$ (chlorophyll b contents), TC (total chlorophyll contents), SFW (shoot fresh weight), $\mathrm{Ci}$ (sub-stomatal $\mathrm{CO}_{2}$ concentration), $\mathrm{Ci} / \mathrm{Ca}\left(C_{i} / C_{a}\right.$ ratio), $\mathrm{RFW}$ (root fresh weight), SDW (shoot dry weight), RDW (root dry weight), AsA (ascorbic acid contents), Pro (proline contents), Phen (phenolic contents), MDA (malondialdehyde contents), $\mathrm{H}_{2} \mathrm{O}_{2}$ (hydrogen peroxide initiation) and GB (glysine betain contents).

\section{Discussion}

The foremost objective of the present study was to determine whether or not exogenous application of glycine betaine (GB) at the rates of 50 and $100 \mathrm{mM}$ could enhance the tolerance of safflower plants against water deficit conditions. Many studies show that water deficiency, for both long and short periods, change the physio-biochemical processes of different crops involved in seed germination, plant growth and yield production $[4,18,41]$. In this study, plant biomass and lengths of root and shoot of safflower plants were reduced due to drought stress. This is analogous to the findings of Aziz et al. [42] in quinoa, Reboucas et al. [43] in cowpea and Jabeen et al. [44] in spinach, in which a significant reduction in growth was observed in safflower plants due to minimal water supply. They found that obstruction in water supply could affect the rate of transpiration and water-use 
efficiency, cause lipid peroxidation and nutritional and hormonal imbalances. While the foliar-applied GB improved the plant biomass and shoot and root lengths of safflower plants under drought stress. Our findings are quite similar to those reported earlier in wheat [45] and corn [46], wherein the researchers had shown a significant improvement in growth due to GB application. Such GB-induced improvement in growth could be attributable to the reason that GB helps in the osmoregulation phenomenon as well as to the protection it provides to cell membranes and proteins $[25,29,32]$.

It has been observed that water deficiency reduces the rate of photosynthesis either because of causing a decrease in the chlorophyll synthesis or damage to its molecules [47-52]. In this study, water shortage reduced the chlorophyll $a$ and $b$ contents and total chlorophyll contents. This is analogous to the finding in water-stressed maize [53] and sunflower [54], where a marked reduction in chlorophyll content has been observed. However, foliar-applied GB enhanced chlorophyll $a$ and $b$ contents of drought-stressed safflower plants. These findings are in agreement with those reported earlier in water-stressed wheat [55] and maize [46]. The GB-induced increase in chlorophyll may be due to its active role in the maintenance of photosystem II and cytoplasmic dehydration. GB can also lower photoinhibition and turgor loss and increase the stress tolerance of photosynthetic machinery $[26,28]$.

Water deficit conditions are believed to reduce turgidity, impair nutrition balance, gas exchange and stomatal regulation [14,56-58], thereby reducing the growth and yield of plants. In our study, water deficiency reduced the $A, A / E$ and $g_{s}$. In our study, water deficiency reduced the photosynthesis rate $(A)$, water use efficiency $(A / E)$ and stomatal conductance $\left(g_{s}\right)$. Our results are similar to those in finger millet [59], wheat [60], barley [61] and cowpea [62]. Exogenously applied GB enhanced the stomatal conductance $\left(g_{s}\right)$, sub-stomatal $\mathrm{CO}_{2}$ concentration $\left(C_{i}\right)$ and $C_{i} / C_{a}$ ratio of safflower plants under drought stress. Similar results were observed in maize [63,64] and sunflower [65]. While critically examining the role of GB in gas exchange characteristics, Ma et al. [46] reported that GB can increase the photosynthetic rate in droughted plants by improving stomatal conductance, which in turn enhances $\mathrm{CO}_{2}$ diffusion.

Under abiotic stresses, particularly drought stress, GB and proline accumulate in plants to a varying extent, which improves the physiological limitations by detoxifying the ROS [66,67]. In our study, drought stress increased proline and GB contents in safflower plants. A number of studies have shown that drought stress can significantly increase the proline level in different plants such as bell pepper [68] and wheat [69]. However, exogenously applied GB enhanced proline and GB accumulation in safflower plants in the present study. Foliar application of GB also increased the proline contents in corn [46] and GB in sunflower [65]. Furthermore, Raza et al. [45] also observed that exogenously applied GB enhanced proline and GB contents in wheat plants under water-deficit conditions. It has been reported that exogenously applied GB reduces damage to biomolecules and protects plants by enhancing the levels of endogenous solutes like GB and proline, resulting in alleviation of the adverse effects of drought stress [27,29].

It has been reported that hydrogen peroxide $\left(\mathrm{H}_{2} \mathrm{O}_{2}\right)$, being an important $\mathrm{ROS}$, helps in signal transduction, particularly under abiotic stresses [3,70]. In the current study, drought stress increased the production of hydrogen peroxide $\left(\mathrm{H}_{2} \mathrm{O}_{2}\right)$ in safflower plants, which is similar to the findings observed in barley [71] and quinoa [42]. However, exogenously applied GB decreased $\mathrm{H}_{2} \mathrm{O}_{2}$ contents in safflower plants under drought stress. Our results are similar to those of Farooq et al. [4] in wheat. They observed a decrease in $\mathrm{H}_{2} \mathrm{O}_{2}$ by exogenous application of GB. It suggests that GB might have some role in the maintenance of ROS or lipid peroxidation [26,64].

It has been widely reported that enzymatic and non-enzymatic antioxidant defense systems help plants to protect against oxidative stress caused by different abiotic stresses [42,72]. AsA scavenges the $\mathrm{H}_{2} \mathrm{O}_{2}$ and other ROS species [4], and it is effective in protecting plants against oxidative damage caused by water shortage $[1,22]$. In the current study, drought stress did not affect the AsA contents in safflower plants, which is contrary to the findings of Secenji et al. [73] in wheat plants. Nevertheless, exogenous application of GB improved the AsA contents in safflower plants under drought stress, but in contrast, the reverse was observed in tobacco by Ma et al. [74]. Against oxidative stress, accumulation of total 
phenolics is vital for maintaining the oxidative stability of fatty acids in different plant species $[3,18,54]$. In the current study, drought stress increased the accumulation of total phenolics in safflower plants, which is in contrast to that reported in maize [64] and rapeseed [1]. Exogenous application of GB improved total phenolics in safflower plants under drought stress. Likewise, GB was effective in enhancing the levels of total phenolics in maize plants $[29,30,63]$. It has been reported that the increase in total phenolics by exogenously applied GB could be due to the fact that GB acts as a signaling substance in plants during drought stress $[25,27,32,74]$.

\section{Conclusions}

Overall, water deficiency markedly suppressed the plant biomass (fresh and dry weight of root and shoot), lengths of root and shoot, chlorophyll $a$ and $b$ contents, total chlorophyll, photosynthesis rate $(A)$, water use efficiency $(A / E)$, stomatal conductance and RWC in both accessions of safflower, while it enhanced proline and GB contents, hydrogen peroxide and total phenolics. Drought stress did not affect the chlorophyll $a / b$ ratio, $E$, stomatal conductance, sub-stomatal $\mathrm{CO}_{2}$ concentration and $C_{i} / C_{a}$ ratio, GB, AsA and MDA contents. Foliar applied GB was effective in enhancing the plant biomass (fresh and dry weight of root and shoot), lengths of root and shoot, chlorophyll $a$ and $b$ contents, stomatal conductance $\left(g_{\mathrm{s}}\right)$, sub-stomatal $\mathrm{CO}_{2}$ concentration $\left(C_{i}\right)$ and $C_{i} / C_{a}$ ratio, proline, $\mathrm{GB}, \mathrm{H}_{2} \mathrm{O}_{2}$, AsA, total phenolics and RWC in safflower plants under water shortage. However, no considerable change was observed in chlorophyll $a / b$ ratio, transpiration rate, photosynthesis rate, water use efficiency and MDA contents due to GB application on both accessions of safflower under drought stress. Therefore, foliar spray of GB could be effective in improving the osmoprotective defense system of both safflower accessions under stress conditions.

Author Contributions: Data curation, Z.N. and N.A.A.; formal analysis, Z.N. and N.A.A.; funding acquisition, S.A. (Shafaqat Ali), A.A.A. and M.N.A.; investigation, Z.N., N.A.A., M.H.S. and S.A. (Shakeel Ahmed); methodology, Z.N.; project administration, M.A., S.A. (Shafaqat Ali), A.A.A. and M.N.A.; software, M.H.S.; supervision, M.A.; visualization, M.A.; writing-original draft, N.A.A., S.A. (Shakeel Ahmed), S.A. (Shafaqat Ali) and M.N.A.; writing-review and editing, M.H.S., S.A. (Shakeel Ahmed) and A.A.A. All authors have read and agreed to the published version of the manuscript.

Funding: The authors highly acknowledge the Higher Education Comission (HEC), Islamabad, Pakistan for its support. The authors would like to extend their sincere appreciation to the Researchers Supporting Project Number (RSP-2020/236), King Saud University, Riyadh, Saudi Arabia.

Acknowledgments: The authors highly acknowledge the Government College University Faisalabad, Pakistan for its support. The authors would like to extend their sincere appreciation to the Researchers Supporting Project Number (RSP-2020/236), King Saud University, Riyadh, Saudi Arabia.

Conflicts of Interest: The authors declare that there is no conflict of interest.

\section{References}

1. Khan, M.N.; Zhang, J.; Luo, T.; Liu, J.; Rizwan, M.; Fahad, S.; Xu, Z.; Hu, L. Seed priming with melatonin coping drought stress in rapeseed by regulating reactive oxygen species detoxification: Antioxidant defense system, osmotic adjustment, stomatal traits and chloroplast ultrastructure perseveration. Ind. Crops Prod. 2019, 140, 111597. [CrossRef]

2. Fahad, S.; Bajwa, A.A.; Nazir, U.; Anjum, S.A.; Farooq, A.; Zohaib, A.; Sadia, S.; Nasim, W.; Adkins, S.; Saud, S. Crop production under drought and heat stress: Plant responses and management options. Front. Plant Sci. 2017, 8, 1147. [CrossRef] [PubMed]

3. Akram, N.A.; Iqbal, M.; Muhammad, A.; Ashraf, M.; Al-Qurainy, F.; Shafiq, S. Aminolevulinic acid and nitric oxide regulate oxidative defense and secondary metabolisms in canola (Brassica napus L.) under drought stress. Protoplasma 2018, 255, 163-174. [CrossRef] [PubMed]

4. Farooq, M.; Irfan, M.; Aziz, T.; Ahmad, I.; Cheema, S. Seed priming with ascorbic acid improves drought resistance of wheat. J. Agron. Crop. Sci. 2013, 199, 12-22. [CrossRef] 
5. Liang, B.; Ma, C.; Zhang, Z.; Wei, Z.; Gao, T.; Zhao, Q.; Ma, F.; Li, C. Long-term exogenous application of melatonin improves nutrient uptake fluxes in apple plants under moderate drought stress. Environ. Exp. Bot. 2018, 155, 650-661. [CrossRef]

6. Bashir, T.; Naz, S.; Bano, A. Plant Growth Promoting Rhizobacteria in Combination with Plant Growth Regulators Attenuate the Effect of Drought Stress. Pak. J. Bot 2020, 52, 783-792. [CrossRef]

7. Alam, H.; Khattak, J.Z.K.; Ksiksi, T.S.; Saleem, M.H.; Fahad, S.; Sohail, H.; Ali, Q.; Zamin, M.; El-Esawi, M.A.; Saud, S. Negative impact of long-term exposure of salinity and drought stress on native Tetraena mandavillei $\mathrm{L}$. Physiol. Plant. 2020. [CrossRef]

8. Saleem, M.H.; Ali, S.; Rehman, M.; Hasanuzzaman, M.; Rizwan, M.; Irshad, S.; Shafiq, F.; Iqbal, M.; Alharbi, B.M.; Alnusaire, T.S. Jute: A Potential Candidate for Phytoremediation of Metals-A Review. Plants 2020, 9, 258. [CrossRef]

9. Saleem, M.H.; Ali, S.; Hussain, S.; Kamran, M.; Chattha, M.S.; Ahmad, S.; Aqeel, M.; Rizwan, M.; Aljarba, N.H.; Alkahtani, S. Flax (Linum usitatissimum L.): A Potential Candidate for Phytoremediation? Biological and Economical Points of View. Plants 2020, 9, 496. [CrossRef]

10. Yaseen, R.; Aziz, O.; Saleem, M.H.; Riaz, M.; Zafar-ul-Hye, M.; Rehman, M.; Ali, S.; Rizwan, M.; Nasser Alyemeni, M.; El-Serehy, H.A. Ameliorating the Drought Stress for Wheat Growth through Application of ACC-Deaminase Containing Rhizobacteria along with Biogas Slurry. Sustainability 2020, 12, 6022. [CrossRef]

11. Saleem, M.; Ali, S.; Rehman, M.; Rana, M.; Rizwan, M.; Kamran, M.; Imran, M.; Riaz, M.; Hussein, M.; Elkelish, A.; et al. Influence of phosphorus on copper phytoextraction via modulating cellular organelles in two jute (Corchorus capsularis L.) varieties grown in a copper mining soil of Hubei Province, China. Chemosphere 2020. [CrossRef] [PubMed]

12. Saleem, M.H.; Kamran, M.; Zhou, Y.; Parveen, A.; Rehman, M.; Ahmar, S.; Malik, Z.; Mustafa, A.; Anjum, R.M.A.; Wang, B. Appraising growth, oxidative stress and copper phytoextraction potential of flax (Linum usitatissimum L.) grown in soil differentially spiked with copper. J. Environ. Manag. 2020, 257, 109994. [CrossRef] [PubMed]

13. Kamran, M.; Parveen, A.; Ahmar, S.; Malik, Z.; Hussain, S.; Chattha, M.S.; Saleem, M.H.; Adil, M.; Heidari, P.; Chen, J.-T. An Overview of Hazardous Impacts of Soil Salinity in Crops, Tolerance Mechanisms, and Amelioration through Selenium Supplementation. Int. J. Mol. Sci. 2019, 21, 148. [CrossRef] [PubMed]

14. Rana, M.; Bhantana, P.; Sun, X.-C.; Imran, M.; Shaaban, M.; Moussa, M.; Hamzah Saleem, M.; Elyamine, A.; Binyamin, R.; Alam, M.; et al. Molybdenum as an Essential Element for Crops: An Overview. Int. J. Sci. Res. Growth 2020, 24, 18535.

15. Saleem, M.H.; Fahad, S.; Khan, S.U.; Ahmar, S.; Khan, M.H.U.; Rehman, M.; Maqbool, Z.; Liu, L. Morpho-physiological traits, gaseous exchange attributes, and phytoremediation potential of jute (Corchorus capsularis L.) grown in different concentrations of copper-contaminated soil. Ecotoxicol. Environ. Saf. 2020, 189, 109915. [CrossRef] [PubMed]

16. Saleem, M.H.; Rehman, M.; Kamran, M.; Afzal, J.; Noushahi, H.A.; Liu, L. Investigating the potential of different jute varieties for phytoremediation of copper-contaminated soil. Environ. Sci. Pollut. Res. 2020, 27, 30367-30377. [CrossRef] [PubMed]

17. Saleem, M.H.; Fahad, S.; Khan, S.U.; Din, M.; Ullah, A.; Sabagh, A.E.L.; Hossain, A.; Llanes, A.; Liu, L. Copper-induced oxidative stress, initiation of antioxidants and phytoremediation potential of flax (Linum usitatissimum L.) seedlings grown under the mixing of two different soils of China. Environ. Sci. Pollut. Res. 2020, 27, 5211-5221. [CrossRef]

18. Hussain, M.I.; Lyra, D.-A.; Farooq, M.; Nikoloudakis, N.; Khalid, N. Salt and drought stresses in safflower: A review. Agron. Sust. Dev. 2016, 36, 4. [CrossRef]

19. Liu, L.; Guan, L.; Wu, W.; Wang, L. A review of fatty acids and genetic characterization of safflower (Carthamus tinctorius L.) seed oil. Org. Chem. Curr. Res. 2016, 5. [CrossRef]

20. Delshad, E.; Yousefi, M.; Sasannezhad, P.; Rakhshandeh, H.; Ayati, Z. Medical uses of Carthamus tinctorius L.(safflower): A comprehensive review from traditional medicine to modern medicine. Electr. Phys. 2018, 10, 6672. [CrossRef]

21. Zhang, T.; Hu, F.; Ma, L. Phosphate-solubilizing bacteria from safflower rhizosphere and their effect on seedling growth. Open Life Sci. 2019, 14, 246-254. [CrossRef] 
22. Khan, M.N.; Zhang, J.; Luo, T.; Liu, J.; Ni, F.; Rizwan, M.; Fahad, S.; Hu, L. Morpho-physiological and biochemical responses of tolerant and sensitive rapeseed cultivars to drought stress during early seedling growth stage. Acta Physiol. Plant. 2019, 41, 25. [CrossRef]

23. Imran, M.; Sun, X.; Hussain, S.; Ali, U.; Rana, M.S.; Rasul, F.; Saleem, M.H.; Moussa, M.G.; Bhantana, P.; Afzal, J. Molybdenum-Induced Effects on Nitrogen Metabolism Enzymes and Elemental Profile of Winter Wheat (Triticum aestivum L.) Under Different Nitrogen Sources. Int. J. Mol. Sci. 2019, 20, 3009. [CrossRef] [PubMed]

24. Rehman, M.; Yang, M.; Fahad, S.; Saleem, M.H.; Liu, L.; Liu, F.; Deng, G. Morpho-physiological traits, antioxidant capacity and nitrogen metabolism in Boehmeria nivea L. under nitrogen fertilizer. Agron. J. 2020. [CrossRef]

25. Annunziata, M.G.; Ciarmiello, L.F.; Woodrow, P.; Dell'Aversana, E.; Carillo, P. Spatial and temporal profile of glycine betaine accumulation in plants under abiotic stresses. Front. Plant Sci. 2019, 10, 230. [CrossRef]

26. Ali, S.; Chaudhary, A.; Rizwan, M.; Anwar, H.T.; Adrees, M.; Farid, M.; Irshad, M.K.; Hayat, T.; Anjum, S.A. Alleviation of chromium toxicity by glycinebetaine is related to elevated antioxidant enzymes and suppressed chromium uptake and oxidative stress in wheat (Triticum aestivum L.). Environ. Sci. Pollut. Res. 2015, 22, 10669-10678. [CrossRef]

27. Ashraf, M.; Foolad, M.R. Roles of glycine betaine and proline in improving plant abiotic stress resistance. Environ. Exp. Bot. 2007, 59, 206-216. [CrossRef]

28. Ashraf, M.; Foolad, M.; Ashraf, M.; Foolad, M. Improving plant abiotic-stress resistance by exogenous application of osmoprotectants glycine, betaine and proline. Environ. Exp. Bot. 2007, 59, 206-216. [CrossRef]

29. You, L.; Song, Q.; Wu, Y.; Li, S.; Jiang, C.; Chang, L.; Yang, X.; Zhang, J. Accumulation of glycine betaine in transplastomic potato plants expressing choline oxidase confers improved drought tolerance. Planta 2019, 249, 1963-1975. [CrossRef]

30. Wang, G.; Li, F.; Zhang, J.; Zhao, M.; Hui, Z.; Wang, W. Overaccumulation of glycine betaine enhances tolerance of the photosynthetic apparatus to drought and heat stress in wheat. Photosynthetica 2010, 48, 30-41. [CrossRef]

31. Rohman, M.M.; Molla, M.; Rahman, M.M.; Ahmed, A.; Biswas, A.; Amiruzzaman, M. Proline and betaine upregulated glutathione dependent detoxification enzymes in tolerant maize seedlings under saline stress. J. Plant. Sci. 2015, 3, 294-302.

32. Gupta, N.; Thind, S.K. Grain yield response of drought stressed wheat to foliar application of glycine betaine. Ind. J. Agric. Res. 2017, 51, 287-291.

33. Arnon, D.I. Copper enzymes in isolated chloroplasts. Polyphenoloxidase in Beta vulgaris. Plant. Physiol. 1949, 24, 1. [CrossRef] [PubMed]

34. Bates, L.S.; Waldren, R.P.; Teare, I. Rapid determination of free proline for water-stress studies. Plant Soil 1973, 39, 205-207. [CrossRef]

35. Grieve, C.; Grattan, S. Rapid assay for determination of water soluble quaternary ammonium compounds. Plant Soil 1983, 70, 303-307. [CrossRef]

36. Velikova, V.; Yordanov, I.; Edreva, A. Oxidative stress and some antioxidant systems in acid rain-treated bean plants: Protective role of exogenous polyamines. Plant Sci. 2000, 151, 59-66. [CrossRef]

37. Cakmak, I.; Horst, W.J. Effect of aluminium on lipid peroxidation, superoxide dismutase, catalase, and peroxidase activities in root tips of soybean (Glycine max). Physiol. Plant. 1991, 83, 463-468. [CrossRef]

38. Julkunen-Tiitto, R. Phenolic constituents in the leaves of northern willows: Methods for the analysis of certain phenolics. J. Agric. Food Chem. 1985, 33, 213-217. [CrossRef]

39. Mukherjee, S.; Choudhuri, M. Implications of water stress-induced changes in the levels of endogenous ascorbic acid and hydrogen peroxide in Vigna seedlings. Physiol. Plant. 1983, 58, 166-170. [CrossRef]

40. Barrs, H.; Weatherley, P. A re-examination of the relative turgidity technique for estimating water deficits in leaves. Aust. J. Biol. Sci. 1962, 15, 413-428. [CrossRef]

41. Naveed, M.; Hussain, M.B.; Zahir, Z.A.; Mitter, B.; Sessitsch, A. Drought stress amelioration in wheat through inoculation with Burkholderia phytofirmans strain PsJN. Plant. Growth Regul. 2014, 73, 121-131. [CrossRef]

42. Aziz, A.; Akram, N.A.; Ashraf, M. Influence of natural and synthetic vitamin C (ascorbic acid) on primary and secondary metabolites and associated metabolism in quinoa (Chenopodium quinoa Willd.) plants under water deficit regimes. Plant Physiol. Biochem. 2018, 123, 192-203. [CrossRef] [PubMed] 
43. Rebouças, D.M.; De Sousa, Y.M.; Bagard, M.; Costa, J.H.; Jolivet, Y.; De Melo, D.F.; Repellin, A. Combined effects of ozone and drought on the physiology and membrane lipids of two cowpea (Vigna unguiculata (L.) Walp) cultivars. Plants 2017, 6, 14. [CrossRef] [PubMed]

44. Jabeen, M.; Akram, N.A.; AZIZ, M.A. ANIQA, Assessment of Biochemical Changes in Spinach (Spinacea oleracea L.) Subjected to Varying Water Regimes. Sains Malays. 2019, 48, 533-541. [CrossRef]

45. Raza, M.; Saleem, M.; Shah, G.; Khan, I.; Raza, A. Exogenous application of glycinebetaine and potassium for improving water relations and grain yield of wheat under drought. J. Soil Sci. Plant Nutr. 2014, 14, 348-364. [CrossRef]

46. Miri, H.R.; Armin, M. The interaction effect of drought and exogenous application of glycine betaine on corn (Zea mays L.). Eur. J. Exp. Biol. 2013, 3, 197-206.

47. Saleem, M.H.; Ali, S.; Rehman, M.; Rizwan, M.; Kamran, M.; Mohamed, I.A.; Bamagoos, A.A.; Alharby, H.F.; Hakeem, K.R.; Liu, L. Individual and combined application of EDTA and citric acid assisted phytoextraction of copper using jute (Corchorus capsularis L.) seedlings. Environ. Technol. Innov. 2020, 19, 100895. [CrossRef]

48. Saleem, M.H.; Ali, S.; Irshad, S.; Hussaan, M.; Rizwan, M.; Rana, M.S.; Hashem, A.; Abd_Allah, E.F.; Ahmad, P. Copper Uptake and Accumulation, Ultra-Structural Alteration, and Bast Fibre Yield and Quality of Fibrous Jute (Corchorus capsularis L.) Plants Grown Under Two Different Soils of China. Plants 2020, 9, 404. [CrossRef]

49. Parveen, A.; Saleem, M.H.; Kamran, M.; Haider, M.Z.; Chen, J.-T.; Malik, Z.; Rana, M.S.; Hassan, A.; Hur, G.; Javed, M.T. Effect of Citric Acid on Growth, Ecophysiology, Chloroplast Ultrastructure, and Phytoremediation Potential of Jute (Corchorus capsularis L.) Seedlings Exposed to Copper Stress. Biomolecules 2020, 10, 592. [CrossRef]

50. Saleem, M.H.; Ali, S.; Kamran, M.; Iqbal, N.; Azeem, M.; Tariq Javed, M.; Ali, Q.; Zulqurnain Haider, M.; Irshad, S.; Rizwan, M. Ethylenediaminetetraacetic Acid (EDTA) Mitigates the Toxic Effect of Excessive Copper Concentrations on Growth, Gaseous Exchange and Chloroplast Ultrastructure of Corchorus capsularis L. and Improves Copper Accumulation Capabilities. Plants 2020, 9, 756. [CrossRef]

51. Saleem, M.H.; Ali, S.; Seleiman, M.F.; Rizwan, M.; Rehman, M.; Akram, N.A.; Liu, L.; Alotaibi, M.; Al-Ashkar, I.; Mubushar, M. Assessing the Correlations between Different Traits in Copper-Sensitive and Copper-Resistant Varieties of Jute (Corchorus capsularis L.). Plants 2019, 8, 545. [CrossRef]

52. Saleem, M.H.; Rehman, M.; Zahid, M.; Imran, M.; Xiang, W.; Liu, L. Morphological changes and antioxidative capacity of jute (Corchorus capsularis, Malvaceae) under different color light-emitting diodes. Braz. J. Bot. 2019, 42, 581-590. [CrossRef]

53. Ahmad, Z.; Waraich, E.A.; Ahmad, R.; Shahbaz, M. Modulation in water relations, chlorophyll contents and antioxidants activity of maize by foliar phosphorus application under drought stress. Pak. J. Bot. 2017, 49, 11-19.

54. Hussain, M.; Farooq, S.; Hasan, W.; Ul-Allah, S.; Tanveer, M.; Farooq, M.; Nawaz, A. Drought stress in sunflower: Physiological effects and its management through breeding and agronomic alternatives. Agric. Water Manag. 2018, 201, 152-166. [CrossRef]

55. Dehghani, I.; Mostajeran, A. Does compatibility of wheat cultivars with Azospirillum brasilense strains affect drought tolerance? Cereal Res. Commun. 2020, 48, 121-129. [CrossRef]

56. Saleem, M.H.; Rehman, M.; Fahad, S.; Tung, S.A.; Iqbal, N.; Hassan, A.; Ayub, A.; Wahid, M.A.; Shaukat, S.; Liu, L.; et al. Leaf gas exchange, oxidative stress, and physiological attributes of rapeseed (Brassica napus L.) grown under different light-emitting diodes. Photosynthetica 2020, 58, 836-845. [CrossRef]

57. Rana, M.S.; Hu, C.X.; Shaaban, M.; Imran, M.; Afzal, J.; Moussa, M.G.; Elyamine, A.M.; Bhantana, P.; Saleem, M.H.; Syaifudin, M. Soil phosphorus transformation characteristics in response to molybdenum supply in leguminous crops. J. Environ. Manag. 2020, 268, 110610. [CrossRef] [PubMed]

58. Rehman, M.; Liu, L.; Wang, Q.; Saleem, M.H.; Bashir, S.; Ullah, S.; Peng, D. Copper environmental toxicology, recent advances, and future outlook: A review. Environ. Sci. Pollut. Res. 2019, 26, 1-14. [CrossRef]

59. Chandra, D.; Srivastava, R.; Glick, B.R.; Sharma, A.K. Drought-tolerant Pseudomonas spp. improve the growth performance of finger millet (Eleusine coracana (L.) Gaertn.) under non-stressed and drought-stressed conditions. Pedosphere 2018, 28, 227-240. [CrossRef]

60. Adrees, M.; Khan, Z.S.; Ali, S.; Hafeez, M.; Khalid, S.; ur Rehman, M.Z.; Hussain, A.; Hussain, K.; Chatha, S.A.S.; Rizwan, M. Simultaneous mitigation of cadmium and drought stress in wheat by soil application of iron nanoparticles. Chemosphere 2020, 238, 124681. [CrossRef] 
61. Schmidthoffer, I.; Szilák, L.; Molnár, P.; Csontos, P.; Skribanek, A. Drought tolerance of European barley (Hordeum vulgare L.) varieties. Agriculture (Pol'nohospodárstvo) 2018, 64, 137-142. [CrossRef]

62. Rivas, R.; Falcão, H.; Ribeiro, R.; Machado, E.; Pimentel, C.; Santos, M. Drought tolerance in cowpea species is driven by less sensitivity of leaf gas exchange to water deficit and rapid recovery of photosynthesis after rehydration. S. Afr. J. Bot. 2016, 103, 101-107. [CrossRef]

63. Maqsood, A.; Shahbaz, M.; Akram, N.A. Influence of Exogenously Applied Glycinebetaine on Growth and Gas Exchange Characteristics of Maize (Zea mays L.). Pak. J. Agric. Sci 2006, 43, 1-2.

64. Anjum, S.A.; Ashraf, U.; Tanveer, M.; Khan, I.; Hussain, S.; Zohaib, A.; Abbas, F.; Saleem, M.F.; Wang, L. Drought tolerance in three maize cultivars is related to differential osmolyte accumulation, antioxidant defense system, and oxidative damage. Front. Plant. Sci. 2017, 8, 69.

65. Iqbal, N.; Ashraf, M.; Ashraf, M. Influence of exogenous glycine betaine on gas exchange and biomass production in sunflower (Helianthus annuus L.) under water limited conditions. J. Agron. Crop. Sci. 2009, 195, 420-426. [CrossRef]

66. Rehman, M.; Liu, L.; Bashir, S.; Saleem, M.H.; Chen, C.; Peng, D.; Siddique, K.H. Influence of rice straw biochar on growth, antioxidant capacity and copper uptake in ramie (Boehmeria nivea L.) grown as forage in aged copper-contaminated soil. Plant. Physiol. Biochem. 2019, 138, 121-129. [CrossRef]

67. Saleem, M.H.; Fahad, S.; Rehman, M.; Saud, S.; Jamal, Y.; Khan, S.; Liu, L. Morpho-physiological traits, biochemical response and phytoextraction potential of short-term copper stress on kenaf (Hibiscus cannabinus L.) seedlings. PeerJ 2020, 8, e8321. [CrossRef]

68. Nath, A.K.; Kumari, S.; Sharma, D. In vitro selection and characterization of water stress tolerant cultures of bell pepper. Ind. J. Plant Physiol. 2005, 10, 14.

69. Qayyum, A.; Razzaq, A.; Ahmad, M.; Jenks, M.A. Water stress causes differential effects on germination indices, total soluble sugar and proline content in wheat (Triticum aestivum L.) genotypes. Afr. J. Biotechnol. 2011, 10, 14038-14045.

70. Zafar, S.; Ashraf, M.Y.; Niaz, M.; Kausar, A.; Hussain, J. Evaluation of wheat genotypes for salinity tolerance using physiological indices as screening tool. Pak. J. Bot. 2015, 47, 397-405.

71. Hossain, B.; Akhtar, M. Growth and yield of barley (Hordeum vulgare L.) as affected by irrigation, sowing method and phosphorus level. Acad. J. Agric. Res. 2014, 2, 30-35.

72. Akram, N.A.; Shafiq, F.; Ashraf, M. Ascorbic acid-a potential oxidant scavenger and its role in plant development and abiotic stress tolerance. Front. Plant Sci. 2017, 8, 613. [CrossRef] [PubMed]

73. Sečenji, M.; Hideg, E.; Bebes, A.; Györgyey, J. Transcriptional differences in gene families of the ascorbate-glutathione cycle in wheat during mild water deficit. Plant. Cell Rep. 2010, 29, 37-50. [CrossRef] [PubMed]

74. Ma, X.; Wang, Y.; Xie, S.; Wang, C.; Wang, W. Glycinebetaine application ameliorates negative effects of drought stress in tobacco. Russ. J. Plant. Physiol. 2007, 54, 472. [CrossRef]

Publisher's Note: MDPI stays neutral with regard to jurisdictional claims in published maps and institutional affiliations.

(C) 2020 by the authors. Licensee MDPI, Basel, Switzerland. This article is an open access article distributed under the terms and conditions of the Creative Commons Attribution (CC BY) license (http://creativecommons.org/licenses/by/4.0/). 